\title{
Obesity and Polycystic Ovary Syndrome
}

\author{
Jana Vrbikova Vojtech Hainer \\ Institute of Endocrinology, Obesity Management Centre, Prague, Czech Republic
}

\section{Key Words \\ Polycystic ovary syndrome · Obesity · Diabetes mellitus}

\begin{abstract}
Summary
Polycystic ovary syndrome (PCOS) is one of the most common endocrinopathies in women of fertile age. Obesity is encountered in $30-70 \%$ of PCOS-affected women, and its presence significantly modifies both clinical and laboratory expression of the syndrome. Obesity increases the risk of co-morbidities associated with PCOS, such as impaired glucose tolerance and type 2 diabetes mellitus, hyperlipidemia and arterial hypertension. The etiopathogenesis of obesity in PCOS has not yet been exactly clarified. There clearly is a vicious circle of abdominal obesity, insulin resistance, and hyperadrogenemia. Differences in ghrelin and neuropeptide $Y$ levels between PCOS patients and those with simple obesity were also described. Weight loss is the first choice recommendation for the treatment of clinical manifestations of PCOS, such as menstrual cycle irregularities, infertility or hirsutism. However, the best treatment approach in obese PCOS patients remains to be defined. Studies concerning different weight loss regimens, antiobesity drugs, bariatric surgery, insulin sensitizers, and hormonal therapy are reviewed.
\end{abstract}

\section{Definition and Diagnosis of Polycystic Ovary Syndrome}

Polycystic ovary syndrome (PCOS) is one of the most common endocrinopathies in women of fertile age and affects up to $6-7 \%$ of this population [1-3]. It is a heterogeneous disorder the principal features of which are androgen excess, ovulatory dysfunction, and polycystic ovaries. The first clinical description of the syndrome dates back to 1935 [4]. However, its pathogenesis has still not yet been fully explained [5].

The study of PCOS has been hampered by the lack of clear diagnostic criteria. It is necessary to emphasize that PCOS is still a 'syndrome', and no single test is diagnostic. The first attempt to define PCOS was undertaken in 1990 by the consensual conference sponsored by the National Institutes of Health (NIH) [6]. Ovulatory dysfunction together with clinical or biochemical hyperandrogenism was defined as necessary for the diagnosis of PCOS, after the exclusion of other specific disorders such as nonclassic adrenal hyperplasia, hyperprolactinemia, hypercortisolism or thyroid dysfunction, which can also lead to similar clinical manifestation. The presence of a morphological picture of polycystic ovaries (PCO) was not required for the establishment of the diagnosis. However, most of European gynecological endocrinologists still stressed the presence of PCO as an important diagnostic feature. Since 1990, it has been also recognized that the syndrome encompasses a broader spectrum of signs and symptoms than those defined in the original NIH diagnostic criteria. Thus, a transatlantic consensual conference was held in Rotterdam in 2003 under the auspices of both prestigious professional gynecogical societies, the European Society for Human Reproduction and Embryology (ESHRE) and the American Society for Reproductive Medicine. The experts stated that PCOS could be diagnosed when any two features out of the following are present: ovulatory dysfunction, clinical or bio-

\begin{tabular}{ll}
\hline KARGER & @ 2009 S. Karger GmbH, Freiburg \\
Fax +497614520714 & Accessible online at: \\
Information@Karger.de & www.karger.com/ofa \\
www.karger.com &
\end{tabular}


Table 1. Comparison of different diagnostic criteria for PCOS

\begin{tabular}{lllll}
\hline Criteria & Ovarian dysfunction & Ovarian morphology & Hyperandrogenism & Exclusion \\
\hline NIH & $\begin{array}{l}\text { oligo-ovulation } \\
\text { (less than } 6 \text { menses per year) }\end{array}$ & not considered & clinical or biochemical (not specified) & other known disorders \\
ESHRE & $\begin{array}{l}\text { oligo-anovulation } \\
\text { (nonspecified) }\end{array}$ & $\begin{array}{l}\text { PCO }(>12 \text { follicles } 2-9 \mathrm{~mm}, \\
\text { or ovarian volume }>10 \mathrm{ml})\end{array}$ & $\begin{array}{l}\text { clinical (hirsutism) or biochemical } \\
\text { (free testosterone or free } \\
\text { testosterone index) }\end{array}$ & disorders with similar \\
AES & oligo-anovulation and/or PCO & $\begin{array}{l}\text { clinical (hirsutism) or } \\
\text { biochemical (free testosterone) }\end{array}$ & $\begin{array}{l}\text { clinical presentation } \\
\text { other androgen excess } \\
\text { and related disorders }\end{array}$ \\
\hline
\end{tabular}

Table 2. The prevalence of overweight and obesity in different cohorts of women with PCOS

\begin{tabular}{llll}
\hline Reference & Country of setting & $\begin{array}{l}\text { Number of } \\
\text { evaluated subjects }\end{array}$ & $\begin{array}{l}\text { BMI } \\
>25 \mathrm{~kg} / \mathrm{m}^{2}, \%\end{array}$ \\
\hline Franks 1989 [16] & UK & 300 & 35 \\
Azziz et al., 2004 [14] & USA & 873 & 80 \\
Glintborg et al., 2004 [17] & Denmark & 125 & 66 \\
Hahn et al., 2007 [18] & Germany & 411 & 66 \\
Cupisti et al., 2008 [15] & Germany & 184 & 60 \\
\hline
\end{tabular}

chemical hyperandrogenism, and PCO [7]. The Rotterdam criteria define, besides two phenotypes which agree with NIH diagnosis, two additional phenotypes $(\mathrm{PCO}+$ ovulatory dysfunction without hyperandrogenism and $\mathrm{PCO}+$ hyperandrogenism without ovulatory dysfunction). Thus, these criteria do not replace but extend the NIH diagnostic criteria. However, a significant controversy about the universal acceptance of the ESHRE criteria evolved [8,9]. It is known that many patients with specific disorders as stated above could have ovulatory dysfunction without hyperandrogenemia or PCO morphology on ultrasound. It cannot be excluded that these subjects could be falsely diagnosed using the Rotterdam ESHRE criteria as having PCOS when an appropriate differential diagnostic evaluation is not performed. Besides this, PCO morphology is seen in up to $20-30 \%$ of otherwise healthy females [10] in whom, when not accompanied by any clinical or laboratory feature of hyperandrogenism, the diagnosis of PCOS is not fulfilled. The presence of metabolic features associated with PCOS in different phenotypic categories according to the Rotterdam criteria is another area of discrepancy. There are to date only few data concerning women with PCOS who fulfilled the ESHRE but not the NIH criteria. Recently it was shown that normoandrogenemic oligomenorrheic women with PCO are metabolically indistinguishable from control women and have significantly fewer metabolic features than PCOS women who are also hyperandrogenemic [11]. Similarly, there was no significant difference in the prevalence of metabolic syndrome between PCOS women manifesting ovulatory dysfunction with PCO and control subjects, even in obese women [12]. It would seem that the above-mentioned new ESHRE phenotypes are not as tightly associated with metabolic disorders as 'classical' PCOS phenotypes.
The most recent modification of the diagnostic criteria of PCOS was suggested by the position statement of the Androgen Excess Society (AES) [13]. AES is an internationally recognized organization dedicated to promote knowledge and research in all aspects of androgen excess disorders. The panel of experts charged by AES has determined that it is metabolic risk, especially insulin resistance, that is the feature which accompanies PCOS, and they have evaluated all large studies concerning PCOS phenotype which have been published with this in mind. Resulting from this approach, the AES position statement confirmed the presence of hyperandrogenism, either clinical or biochemical, as a necessary prerequisite for PCOS diagnosis (table 1).

\section{Pathogenetic Links between Obesity and Polycystic Ovary Syndrome}

Obesity is common in PCOS and affects between $30-70 \%$ of women depending on the setting of the study and the ethnical background of the subjects [14-18] (table 2). On the other hand, PCOS was found in nearly $30 \%$ of morbidly obese women, compared with only $5 \%$ of the lean population [19]. However, as not all morbidly obese women develop PCOS, some primary abnormality in androgen production is supposed as necessary for the development of the syndrome [20]. On the other hand, there is much evidence suggesting that hyperandrogenemia could aggravate visceral obesity in women, in contrast to men where beneficial effects of testosterone were recognized [21, 22]. Androgen promoted central fat deposition in female-to-male transsexuals [23]. Testosterone increased lipogenesis in visceral fat deposits in women [24]. Premeno- 
pausal women with central obesity had higher testosterone production rates than those with peripheral obesity [25]. Antiandrogen therapy decreased adiposity in females with hyperandrogenism [26, 27]. Furthermore, the association of hyperandrogenemia and insulin resistance in women is supported by the finding of partial improvement in insulin sensitivity after antiandrogen treatment $[28,29]$.

The pathogenetic importance of obesity in the development of PCOS is stressed by the results of a prospective study determining the relationship between body size and self-reported PCOS symptoms. Both abdominal obesity and weight gain after adolescence were predictive for the development of PCOS. An increased risk of self-reported PCOS symptoms was observed among 30-year-old overweight or abdominally obese women who had either normal weight in adolescence or who were overweight or obese at both adolescence and adult age. Furthermore, to stress the role of obesity, about $30-40 \%$ of symptomatic cases of PCOS could have been prevented if these women had normal body weight [30].

PCOS has a strong heritable component. Recently, the Dutch twin study demonstrated that the concordance in monozygotic twin sisters for PCOS was about twice higher than in dizygotic twin and other sisters (correlation 0.71 vs. 0.38) [31], which suggested an oligogenic genetic component. Nearly 70 genes have been evaluated till now using candidate gene approach in genetic studies conducted in different populations of women affected with PCOS. Unfortunately, these studies yielded very disparate results, obviously due to small sample sizes and complex PCOS phenotype. Studies concerning functional candidate genes for human obesity, such as pro-opiomelanocortin, leptin and leptin receptor, uncoupling proteins 2 and 3, melanocortin 4 receptor and adiponectin, gave mostly unconvincing or negative results as was reviewed by Urbanek [32]. Recently, fat mass and obesity associated gene (FTO) has been identified as an obesity-related gene using a genome-wide association study approach by two independent research groups $[33,34]$. The cluster of common SNPs in intron 1 was strongly associated with type 2 diabetes mellitus (T2DM); however, this association was abolished after BMI adjustment, suggesting that the association was mediated by adiposity. The influence of FTO on BMI is modest but consistent in Caucasians. Each risk allele increases BMI by $0.4-0.6 \mathrm{~kg} / \mathrm{m}^{2}$. The conflicting reports whether the FTO variants influence features of metabolic syndrome were recently addressed in a meta-analysis comprising of about 17,000 subjects [35]. The authors concluded that FTO variant in intron 1 was associated with metabolic traits to an extent entirely consistent with BMI effect. However, an independent association between glucose intolerance and SNP rs1421085 in intron 1 was described in a smaller Causasian cohort of PCOS-affected women [36]. The exact mechanism how the FTO product could affect energy balance has not been clarified till now [37]. FTO is abundantly expressed in the hypothalamus [33]. However, its peripheral effects on fat lipolysis were also reported [38].
In 2008, a strong association was found between FTO variant rs9939609 in intron 1 and PCOS status. This association was weakened but not eradicated after BMI adjustment. However, it was also much weaker when restricted to leaner PCOS subgroups. The authors suggested that the effect of FTO on PCOS susceptibility was mediated through its effect on fat mass and that the association seen after BMI adjustment was due to sampling error [39].

One of the theories on the pathogenesis of PCOS suggests as the primary defect the exaggerated ovarian androgen production. There is clear evidence supporting an increased transcription of genes encoding specific steroidogenic enzymes, and this leads to the increased production of progestins and androgens [40]. The steroidogenic abnormalities associated with PCOS in long-term theca cells culture are characterized by an increase in 3 $\beta$-hydroxysteroid dehydrogenase type II

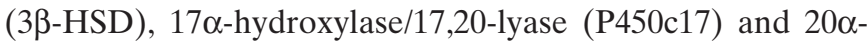
hydroxysteroid dehydrogenase (20 $\alpha$-HSD) enzyme activities and an increased mRNA accumulation for P450-side chain

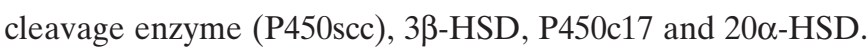
On the other hand, similar mRNA levels of steroidogenic acute regulatory protein (StAR) and $17 \beta$-hydroxysteroid dehydrogenase type V (17 $\beta$-HSDV) between PCOS and healthy women were found. Furthermore, some of above stated defects could be manifested by the hyperinsulinism and insulin resistance [41].

Obesity could aggravate all of the clinical manifestations of PCOS [42]. Obese PCOS patients are more hirsute and have higher androgen levels than their lean counterparts as reviewed recently by Hoeger [43]. Moreover, obesity alone is associated with an increased risk of infertility [44]. Many features of PCOS are completely resolved by the weight loss following bariatric surgery [19].

It is still not clear if there are consistent differences in the levels or in the effects of appetite-regulating hormones as is ghrelin, neuropeptide Y (NPY) or cholecystokinin in PCOS. Fasting ghrelin was found to be reduced in most [45-49], but not all studies [50, 51]. A blunted suppression of ghrelin after test meals and significantly greater hunger and lower satiety scores on visual analogue scales were described in a small cohort of obese PCOS women even after weight reduction [47] and recently confirmed in another study comprising of both lean and obese PCOS patients and weight-matched controls [52]. No difference in fasting or postprandial levels of peptide YY and cholecystokinin before or after weight loss was seen in obese PCOS patients [53]. Discrepant data about plasma NPY levels in PCOS still exist. Baranowska and colleagues [54] observed lower basal NPY concentrations in obese PCOS women compared to the weight-matched controls. In contrast, Gennarelli et al. [55] reported similar NPY levels at rest in PCOS and normo-ovulatory women, but an impaired NPY response to hypoglycemia in PCOS women.

To conclude, abdominal obesity is considered an important factor contributing to ovarian and possibly adrenal hyper- 
androgenism. However, androgen excess itself might also contribute to abdominal fat deposition in hyperandrogenic women. The exact clarification of an interplay between fat tissue, ovarian and adrenal steroid production and insulin sensitivity, similarly as of the role of genetic factors in PCOS and obesity pathophysiology, still remains a hot topic for future research.

\section{Cardiovascular Risk Factors in Polycystic Ovary Syndrome - Is Obesity the Culprit?}

PCOS is a lifelong lasting disease. It has been recognized that PCOS is associated with metabolic abnormalities such as insulin resistance, dyslipidemia, chronic low-grade inflammation, and arterial hypertension [56, 57]. However, all of these abnormalities are also more common in obese subjects, and thus the specific influence of PCOS is often difficult to establish.

The prevalence of both impaired glucose tolerance (IGT) and T2DM is increased in PCOS women even early in their fertile age [58-62], and obesity further increases the risk for IGT/T2DM. Moreover, obese PCOS women had 7- to 10-fold increase in the conversion rate from normal glucose tolerance to IGT or T2DM in comparison with normal weight subjects [63]. Evidence regarding the risk of IGT in lean PCOS women however is limited $[64,65]$. Therefore, the minority report of the recent position statement concerning screening for IGT and T2DM in PCOS [66] suggested using oral glucose tolerance test (OGTT) only in obese patients or, alternatively, screening lean patients only if they have at least one additional risk factor for T2DM such as advanced age, family history of T2DM or a personal history of gestational diabetes.

Obesity also influences the association of PCOS with metabolic syndrome. In a relatively lean (BMI $24 \pm 4.8 \mathrm{~kg} / \mathrm{m}^{2}$ ) Czech PCOS cohort, overt metabolic syndrome according to ATP III criteria was not more common than in healthy controls [67]. Similarly, in Brazilian PCOS patients the prevalence of metabolic syndrome increased from $3.2 \%$ in lean to $52.3 \%$ in obese women [68]. On the contrary, metabolic syndrome was diagnosed in $46 \%$ of white American women with PCOS [69]. Recently, a similar study in the US population has confirmed these data [70]; the authors described that the prevalence of metabolic syndrome in PCOS women was twice as high as that found in the general population data [70]. The observed discrepancies could be explained by the fact that the US women were significantly more obese $(85 \%$ with a waist circumference of over $88 \mathrm{~cm}$ in [69] or BMI between 31.7 and $\left.42 \mathrm{~kg} / \mathrm{m}^{2}\right)$.

Arterial hypertension is another important risk factor for coronary heart disease. There are, to date, only a few studies concerning blood pressure in PCOS, as reviewed by Wild [71]. Recently, obesity was found as the major determinant of blood pressure abnormalities during 24-hour monitoring [72].
Dyslipidemia characteristic for metabolic syndrome with a decrease in HDL cholesterol, increase in triglycerides, and increase in small dense LDL is found in women with PCOS $[73,74]$. Obesity aggravates this pattern [75]. Non-classical risk factors of coronary heart disease, as markers of chronic inflammation, were found to be more strongly associated with obesity than with PCOS per se in some studies [76, 77]. Similarly, a recent study found impaired microcirculatory function after insulin infusion only in obese, but not in lean PCOS [78].

It is thus possible to conclude that the relative independent contribution of obesity and PCOS to cardiovascular risk factors is still not fully clarified and that data concerning separate clinical endpoints for lean and obese PCOS patients are lacking.

\section{Depression, Health-Related Quality of Life and Polycystic Ovary Syndrome}

A significantly increased prevalence of depression and anxiety in women with PCOS was described using validated questionnaires [79-81] and verified using structured clinical assessment [82, 83]. Significantly impaired health-related quality of life (QoL) in PCOS was also described repeatedly as reviewed recently by Jones et al. [84].

There are to date only sparse and discrepant data about possible pathogenetical links between PCOS and depression. Some $[85,86]$, but not all [81] studies found an association between hyperandrogenemia and symptoms of depression. Insulin resistance could be another factor connected with both depression and PCOS [87, 88]. The risk of depression was independent of present obesity, even when depressed women in this study had higher BMI than non-depressed women [81]. Similarly, the relationship between BMI and health-related QoL is complex. The lack of a relationship between BMI and QoL indicate that all women with PCOS, regardless of their BMI measurement, have weight concerns and that PCOS women with a normal BMI struggle to maintain their weight at this level [84].

\section{Treatment Approaches (Table 3)}

Therapeutical options specifically targeted to influence hyperandrogenic symptoms are combined oral contraceptives (COC) and antiandrogens. Obesity influenced markedly the effect of both of these treatment modes on androgen levels and androgenic symptoms. A recently published meta-analysis has shown the reduced efficacy of antiandrogens for the treatment of hirsutism in obese PCOS patients [89]. Similarly, the positive effect of COC treatment on androgen production, serum androgen binding capacity, and clinical androgenic symptoms was diminished in obese subjects [90]. 
Table 3. Symptomatic therapy in women with PCOS

\begin{tabular}{ll}
\hline Symptom & Therapy \\
\hline Hirsutism/acne & $\begin{array}{l}\text { combined oral contraceptives } \\
\text { antiandrogenes } \\
\text { laser therapy } \\
\text { weight reduction }\end{array}$ \\
Irregular menstrual cycle & $\begin{array}{l}\text { combined oral contraceptives } \\
\text { weight reduction } \\
\text { metformin }\end{array}$ \\
Infertility & $\begin{array}{l}\text { weight reduction } \\
\text { clomiphen citrate } \\
\text { gonadotropines } \\
\text { aromatase inhibitors } \\
\text { metformin } \\
\text { in vitro fertilization }\end{array}$ \\
\hline
\end{tabular}

The effect of COC on insulin sensitivity and glucose tolerance in PCOS was inconsistent, as was reviewed by Nader and Diamanti-Kandarakis [91]. Insulin sensitivity may decrease in PCOS, and the effect could be again modified primarily by the degree of obesity, with a decrease in obese women only $[92,93]$. It is possible that the composition of COC could also play a role as only the higher-, but not the low-dose estrogen COC increased insulin resistance by $25 \%$ in an obese cohort of PCOS [94]. The studies comparing different COC products are however sparse, and therefore it is not possible to conclude whether some combinations are superior to others. It should be emphasized that all available studies are limited in the duration of hormone use, and long-term effects are not known [95]. Based on the observation of lower effectivity of both COC and antiandrogens in obese PCOS women, lifestyle modification is important in a complex treatment approach. In the general population, COC treatment is not free of serious side effects. Second-generation COC were associated with a 1.85 and 2.54 times increased risk of myocardial infarction and ischemic stroke events, respectively, and third-generation COC were connected with a 2.0 times increased risk for ischemic stroke outcome [96]. Similar data specific for PCOS women are unfortunately lacking. However, as obese women with PCOS exhibit many of the risk factors of coronary heart disease, the possible exacerbation of adverse long-term outcomes of PCOS by COC may be taken into account when deciding about therapy.

Insulin sensitizers were shown to normalize menstrual irregularity [97]. However, they were not as effective as antiandrogens in the improvement of hirsutism $[98,99]$. In the UKPDS study [100], metformin significantly reduced stroke, diabetesrelated endpoints and all-cause mortality compared with intensive treatment with insulin or sulphonylurea, despite similar glycemic control in T2DM. However, a meta-analysis of studies in T2DM patients did not find a significant treatment effect of metformin on blood pressure, HDL cholesterol, and triglycerides [101]. The hypothesis that insulin sensitizers could be superior for metabolic aspects of PCOS in comparison with COC was tested in few short-term randomized trials [102-104] which are summarized recently in a meta-analysis [105]. Fasting insulin and triglycerides decreased after metformin, however they did not change after COC treatment. Fasting glucose or total cholesterol did not change after any of the treatment modes. COC, in contrast to metformin, decreased markedly serum testosterone and improved menstrual cycle pattern. However, all of the studies included in the meta-analysis were relatively small and short-term lasting. Thus, it is not possible to definitively conclude if any of these treatment modes is superior over the others.

Thiazolidinediones as another class of insulin sensitizers were also used in clinical trials in PCOS. They decreased both fasting and post load glucose and insulin values [106, 107] and improved hyperandrogenism and ovulation rates [106, 107], thereby providing both metabolic and reproductive benefits. However, some of the effects of glizatones are not common for all of these drugs. For example, both drugs affect lipid metabolism differently. Rosiglitazone increased both triglycerides and LDL particle concentration, and pioglitazone led to significant improvements in triglycerides, HDL cholesterol, LDL particle concentration and LDL particle size [108]. Recently, the results of a trial randomly assigning obese PCOS women to rosiglitazone or COC treatment were published. Rosiglitazone reduced insulin resistance but had limited effect on lipids, androgens, and hirsutism. COC did not modify insulin resistance but increased high-density lipoprotein cholesterol and triglycerides and decreased androgens and hirsutism [109]. As far as is known to us, no trial combining COC and pioglitazone has been published.

Glitazones are not free of side effects. They led to an increase in weight in some trials in PCOS $[106,107,110]$. Another point of concern is the negative influence of rosiglitazone on cardiovascular mortality [111]. Both pioglitazone and rosiglitazone are pregnancy category $\mathrm{C}$ drugs as they caused increased fetal loss and retarded fetal growth even if they appeared unlikely to increase the risk of congenital malformations in animal studies. There have been no controlled studies in women, and there are no published studies on their use during human pregnancy. Their use in women of fertile age is thus limited.

Weight reduction is the first-line intervention in obese PCOS women. It was shown that as little as a 5\% decrease in body weight restored ovulation in anovulatory obese PCOS patients $[112,113]$, and weight loss of about $10 \%$ was associated with a $50 \%$ chance of returning ovulation [114]. Moreover, a weight reduction as little as $5 \%$ has been shown to reduce insulin resistance and testosterone levels [47, 112, 113, 115-119]. These results are similar to the data from the general population, showing that a weight loss of 5-7\% exerted significant benefit in cardiovascular risk factors and in the reduction of incidence of T2DM [120].

Concerning infertility, weight loss was shown to increase ovulatory rates as stated previously. A trial of complex lifestyle 
improvement lasting at least 6 months is recommended as the first-line approach before any specific infertility treatment is started [121]. Clomiphene citrate (CC) still remains the firstchoice medication for the induction of ovulation even if it is not possible to discern if metformin could be more effective [122]. Another promising drug group are aromatase inhibitors which are free of the unwanted effects of $\mathrm{CC}$ on endometrium. However, their place in the treatment is not fully defined till now [123].

Not only caloric density reduction, but also macronutrient content of diet could be of concern in the complex management of PCOS. There are to date few and discrepant data about the acute and short-term effects of dietary composition in PCOS. Recently, a small study $(\mathrm{n}=15)$ including women with very large range of BMI showed surprisingly that testosterone remained below pre-meal values significantly longer after the ingestion of high-fat meal than after a low-fat, high-fiber meal. In this study, no effect of meal composition on postprandial DHEAS, cortisol, and SHBG levels was observed [124]. On the contrary, oral glucose ingestion led to an increase in plasma cortisol and adrenal androgens and to reactive hypoglycemia in comparison with whey protein ingestion in overweight/obese PCOS [125]. High-protein or a high-carbohydrate diet induced similar weight loss and a similar degree of improvement in circulating androgens, measures of glucose metabolism, and leptin in a small pilot study lasting 4 weeks [126]. Another short-term study compared eucaloric diets either enriched with monounsaturated fatty acids or low in carbohydrates with a standard diet among women with PCOS and described lower fasting insulin and lower acute insulin response to glucose after low-carbohydrate diet [127]. An increased intake of polyunsaturated fatty acids led to a reduction in plasma free fatty acids and to an increase in fasting glucose but exerted no changes in insulin and steroid hormones [128]. Recently, high-protein, low-carbohydrate diet, but not low-protein, high-carbohydrate diet was associated with significant improvement in ratings of depression and self-esteem despite the fact that both regimens led to a similar decrease in body weight [129]. A 6-month trial comparing moderate fat or carbohydrate restriction has shown that both are equally effective in maintaining weight reduction and improving reproductive and metabolic variables [130]. Relatively little attention was paid to diets with different glycemic index in PCOS [130]. This point could be of concern, as diets with low glycemic index generally improved insulin resistance, influenced blood lipid concentrations and inflammation [131], and reduced the risk of endometrial cancer [132].

Most of the above cited trials were relatively small and shortterm. Further studies concerning both acute effects of different macronutrients and different dietary composition for longer periods on both hormonal and metabolic environment and psychological aspects in PCOS are thus highly warranted. Metformin decreased BMI significantly in the pioneering observational study of Velazquez et al. [133]. Recently, a meta-analysis of 14 trials including 649 women and comparing metformin and placebo with or without lifestyle modification showed a statistically significant decrease in BMI after treatment (weighted mean difference, -0.68 ; $95 \% \mathrm{CI}-1.13$ to -0.24) [134]. There was some indication that a high dose of metformin (>1,500 mg/day) and longer duration of therapy may have greater effect. However, only 3 out of 14 trials used intention-to-treat analysis, and most of them were designed for a different primary outcome. The authors concluded that adequately powered randomized trials are required to confirm the findings and to assess whether the addition of highdose metformin therapy to a structured lifestyle modification program might contribute to a more profound weight loss.

All of the drugs recommended for use as antiobesity agents were used in PCOS, and all of them led to similar weight decrease as was described in studies conducted in the general population [135].

Orlistat treatment in obese PCOS patients led to a weight loss, reduced testosterone levels [136-139]. and improved insulin sensitivity in some [137, 139], but not all studies [138]. However, all the studies presented were relatively short-term (lasting between 3 and 6 months) and were not aimed to evaluate changes in menstrual cyclicity or in clinical signs of hyperandrogenism.

Sibutramine was added to the hypocaloric diet in an openlabel randomized study lasting 6 months. Sibutramine caused greater weight loss (15 vs. $11 \%)$, together with greater decrease in AUC for glucose during OGTT than diet only. Free androgen index also declined more profoundly in the sibutramine arm [140]. Similarly, in a placebo-controlled 6-month trial, sibutramine led to a more profound weight loss than lifestyle modification (9 vs. $1.7 \%$ ) as well as to a greater increase in SHBG and a greater improvement in triglycerides and apoB levels [141]. Both sibutramine and weight reduction 'only' improved menstrual cycle frequency significantly but had no effect on insulin sensitivity, blood pressure or on androgen levels [141]. A small study comparing sibutramine, COC and their combination administered together with hypocaloric diet described similar decrease of BMI in all groups. Sibutramine in monotherapy was superior in the improvement of insulin sensitivity and triglycerides; however, this positive effect was not apparent in the combined treatment group. Androgen levels and hirsutism improved similarly in all groups [142].

Recently, rimonabant was used in a randomized trial with metformin in 20 women with PCOS. Body weight, insulin resistance, and testosterone levels decreased after rimonabant, but not after metformin [143]. However, one of the unwanted side effects of cannabinoid receptor blockers is depression, which was reported in $26 \%$ of subjects given $20 \mathrm{mg}$ of rimonabant [144].

During postmarketing surveillance, it was recognized that there was approximately doubling of the risk of psychiatric disorders in patients taking rimonabant (Acomplia ${ }^{\circledR}$, Sanofi- 
Aventis, Berlin, Germany) compared with placebo. Moreover, patients at an elevated risk of developing psychiatric disorders could not be identified in advance. Resulting from these facts European Medical Agency (EMEA) has recommended the suspension of marketing authorization for this formulation [145]. Antidepressants could be effective in weight reduction [146]. However, as far as we know, there have been no trials with these drugs in PCOS.

Bariatric surgery is currently viewed as the most effective approach for the treatment of morbid obesity [147]. Several studies have shown improvement in fertility in women of reproductive age after surgery-induced weight loss [148]. Two small studies on the effects of bariatric surgery in morbidly obese PCOS women have been published up to now. A retrospective study evaluated 30 women with PCOS who underwent laparoscopic Roux-en-Y gastric bypass. All of them had complete resolution of their menstrual irregularity, $75 \%$ of them had marked improvement in hirsutism score, and all who wished to be pregnant were able to conceive spontaneously. Moreover, all subjects with T2DM were normoglycemic at the follow-up, normal blood pressure without antihypertensive treatment was restored in $78 \%$ of the formerly hyperten- sive subjects, and $92 \%$ of the formerly dyslipidemic subjects no longer required hypolipidemic drugs [149]. These results were confirmed in a prospective study evaluating 17 women with PCOS. All but one subject demonstrated marked improvement in clinical and biochemical hyperandrogenism and in insulin resistance [19].

In conclusion, obesity is often encountered in PCOS and modifies significantly both hormonal and metabolic phenotypes of these women. In addition, obese PCOS women have worse therapeutical response to some treatment modalities than their lean counterparts, and the best therapeutical regimen for them remains to be defined.

\section{Achnowledgement}

Supported with the grants of Internal Grant Agency of Czech Ministry of Health NB 6696-3, NR 8759-3 and NS 9839-4.

\section{Disclosure}

The authors declared no conflict of interest.

\section{References}

1 Asuncion M, Calvo RM, San Millan JL, Sancho J, Avila S, Escobar-Morreale HF: A prospective study of the prevalence of the polycystic ovary syndrome in unselected Caucasian women from Spain. J Clin Endocrinol Metab 2000;85:2434-2438.

2 Azziz R, Woods KS, Reyna R, Key TJ, Knochenhauer ES, Yildiz BO: The prevalence and features of the polycystic ovary syndrome in an unselected population. J Clin Endocrinol Metab 2004;89:27452749.

3 Diamanti-Kandarakis E, Kouli CR, Bergiele AT, Filandra FA, Tsianateli TC, Spina GG, Zapanti ED, Bartzis MI: A survey of the polycystic ovary syndrome in the Greek island of Lesbos: hormonal and metabolic profile. J Clin Endocrinol Metab 1999;84:4006-4011.

$\checkmark 4$ Stein IF, Leventhal ML: Amenorhoea associated with bilateral polycystic ovaries. Am J Obstet Gynecol 1935;29:181-186.

5 Norman RJ, Dewailly D, Legro RS, Hickey TE: Polycystic ovary syndrome. Lancet 2007;370:685697.

6 Zawadzki JA, Dunaif A: Diagnostic criteria for polycystic ovary syndrome: towards a rationale approach; in Dunaif A, Givens JR, Haseltine FP, Merriam GR (eds): Polycystic Ovary Syndrome. Boston, Blackwell Scientific, 1992, pp 377-384.

7 Revised 2003 consensus on diagnostic criteria and long-term health risks related to polycystic ovary syndrome (PCOS). Hum Reprod 2004;19:41-47.

$\checkmark$ Azziz R: Controversy in clinical endocrinology: diagnosis of polycystic ovarian syndrome: the Rotterdam criteria are premature. J Clin Endocrinol Metab 2006;91:781-785.

9 Franks S: Diagnosis of polycystic ovary syndrome: in defense of the Rotterdam criteria. J Clin Endocrinol Metab 2006;91:786-789.
10 Clayton RN, Ogden V, Hodgkinson J, Worswick L, Rodin DA, Dyer S, Meade TW: How common are polycystic ovaries in normal women and what is their significance for the fertility of the population? Clin Endocrinol (Oxf) 1992:37:127-134.

11 Barber TM, Wass JA, McCarthy MI, Franks S: Metabolic characteristics of women with polycystic ovaries and oligo-amenorrhoea but normal androgen levels: implications for the management of polycystic ovary syndrome. Clin Endocrinol (Oxf) 2007;66:513-517.

12 Shroff R, Syrop CH, Davis W, Van Voorhis BJ, Dokras A: Risk of metabolic complications in the new PCOS phenotypes based on the Rotterdam criteria. Fertil Steril 2007;88:1389-1395.

13 Azziz R, Carmina E, Dewailly D, DiamantiKandarakis E, Escobar-Morreale HF, Futterweit W, Janssen OE, Legro RS, Norman RJ, Taylor AE, Witchel SF: Positions statement: criteria for defining polycystic ovary syndrome as a predominantly hyperandrogenic syndrome: an Androgen Excess Society guideline. J Clin Endocrinol Metab 2006;91:4237-4245.

14 Azziz R, Sanchez LA, Knochenhauer ES, Moran C, Lazenby J, Stephens KC, Taylor K, Boots LR: Androgen excess in women: experience with over 1000 consecutive patients. J Clin Endocrinol Metab 2004;89:453-462.

15 Cupisti S, Kajaia N, Dittrich R, Duezenli H, Beckmann MW, Mueller A: Body mass index and ovarian function are associated with endocrine and metabolic abnormalities in women with hyperandrogenic syndrome. Eur J Endocrinol 2008;158:711-719.

16 Franks S: Polycystic ovary syndrome: a changing perspective. Clin Endocrinol (Oxf) 1989;31:87-120.
17 Glintborg D, Henriksen JE, Andersen M, Hagen C, Hangaard J, Rasmussen PE, Schousboe K, Hermann AP: Prevalence of endocrine diseases and abnormal glucose tolerance tests in 340 Caucasian premenopausal women with hirsutism as the referral diagnosis. Fertil Steril 2004;82:1570-1579.

18 Hahn S, Tan S, Sack S, Kimmig R, Quadbeck B, Mann K, Janssen OE: Prevalence of the metabolic syndrome in German women with polycystic ovary syndrome. Exp Clin Endocrinol Diabetes 2007;115:130-135.

19 Escobar-Morreale HF, Botella-Carretero JI, Alvarez-Blasco F, Sancho J, San Millan JL: The polycystic ovary syndrome associated with morbid obesity may resolve after weight loss induced by bariatric surgery. J Clin Endocrinol Metab 2005;90:63646369.

20 Martinez-Bermejo E, Luque-Ramirez M, EscobarMorreale HF: Obesity and the polycystic ovary syndrome. Minerva Endocrinol 2007;32:129-140.

21 Marin P, Holmang S, Gustafsson C, Jonsson L, Kvist H, Elander A, Eldh J, Sjostrom L, Holm G, Bjorntorp P: Androgen treatment of abdominally obese men. Obes Res 1993;1:245-251.

22 Allan CA, Strauss BJ, Burger HG, Forbes EA, McLachlan RI: Testosterone therapy prevents gain in visceral adipose tissue and loss of skeletal muscle in nonobese aging men. J Clin Endocrinol Metab 2008;93:139-146.

23 Elbers JM, Giltay EJ, Teerlink T, Scheffer PG, Asscheman H, Seidell JC, Gooren LJ: Effects of sex steroids on components of the insulin resistance syndrome in transsexual subjects. Clin Endocrinol (Oxf) 2003;58:562-571.

24 Bjorntorp P: The regulation of adipose tissue distribution in humans. Int J Obes Relat Metab Disord 1996;20:291-302. 
-25 Kirschner MA, Samojlik E, Drejka M, Szmal E, Schneider G, Ertel N: Androgen-estrogen metabolism in women with upper body versus lower body obesity. J Clin Endocrinol Metab 1990;70:473-479.

26 Gambineri A, Pagotto U, Tschop M, Vicennati V, Manicardi E, Carcello A, Cacciari M, De Iasio R, Pasquali R: Anti-androgen treatment increases circulating ghrelin levels in obese women with polycystic ovary syndrome. J Endocrinol Invest 2003;26:629-634.

-27 Ibanez L, Ong K, Ferrer A, Amin R, Dunger D, de Zegher F: Low-dose flutamide-metformin therapy reverses insulin resistance and reduces fat mass in nonobese adolescents with ovarian hyperandrogenism. J Clin Endocrinol Metab 2003;88:2600-2606.

28 Dahlgren E, Landin K, Krotkiewski M, Holm G, Janson PO: Effects of two antiandrogen treatments on hirsutism and insulin sensitivity in women with polycystic ovary syndrome. Hum Reprod 1998;13 2706-2711.

-29 Moghetti P, Tosi F, Castello R, Magnani C M, Negri C, Brun E, Furlani L, Caputo M, Muggeo $\mathrm{M}$ : The insulin resistance in women with hyperandrogenism is partially reversed by antiandrogen treatment: evidence that androgens impair insulin action in women. J Clin Endocrinol Metab 1996; 81:952-960.

-30 Laitinen J, Taponen S, Martikainen H, Pouta A, Millwood I, Hartikainen AL, Ruokonen A, Sovio U, McCarthy MI, Franks S, Jarvelin MR: Body size from birth to adulthood as a predictor of selfreported polycystic ovary syndrome symptoms. Int J Obes Relat Metab Disord 2003;27:710-715.

-31 Vink JM, Sadrzadeh S, Lambalk CB, Boomsma DI: Heritability of polycystic ovary syndrome in a Dutch twin-family study. J Clin Endocrinol Metab 2006;91:2100-2104.

32 Urbanek M: The genetics of the polycystic ovary syndrome. Nat Clin Pract Endocrinol Metab 2007;3: 103-111.

33 Frayling TM, Timpson NJ, Weedon MN, Zeggini E, Freathy RM, Lindgren CM, Perry JR, Elliott KS, Lango H, Rayner NW, Shields B, Harries LW, Barrett JC, Ellard S, Groves CJ, Knight B, Patch AM, Ness AR, Ebrahim S, Lawlor DA, Ring SM, Ben-Shlomo Y, Jarvelin MR, Sovio U, Bennett AJ, Melzer D, Ferrucci L, Loos RJ, Barroso I, Wareham NJ, Karpe F, Owen KR, Cardon LR, Walker M, Hitman GA, Palmer CN, Doney AS, Morris AD, Smith GD, Hattersley AT, McCarthy MI: A common variant in the FTO gene is associated with body mass index and predisposes to childhood and adult obesity. Science 2007;316:889-894.

\34 Scuteri A, Sanna S, Chen W M, Uda M, Albai G, Strait J, Najjar S, Nagaraja R, Orru M, Usala G, Dei M, Lai S, Maschio A, Busonero F, Mulas A, Ehret GB, Fink AA, Weder AB, Cooper RS, Galan P, Chakravarti A, Schlessinger D, Cao A, Lakatta E, Abecasis GR: Genome-wide association scan shows genetic variants in the FTO gene are associated with obesity-related traits. PLoS Genet 2007:3:e115.

35 Freathy RM, Timpson NJ, Lawlor DA, Pouta A, Ben-Shlomo Y, Ruokonen A, Ebrahim S, Shields B, Zeggini E, Weedon MN, Lindgren CM, Lango H, Melzer D, Ferrucci L, Paolisso G, Neville MJ, Karpe F, Palmer CN, Morris AD, Elliott P, Jarvelin MR, Smith GD, McCarthy MI, Hattersley AT, Frayling TM: Common variation in the FTO gene alters diabetes-related metabolic traits to the extent expected given its effect on BMI. Diabetes 2008; 57:1419-1426.
36 Attaoua R, Ait El Mkadem S, Radian S, Fica S, Hanzu F, Albu A, Gheorghiu M, Coculescu M, Grigorescu F: FTO gene associates to metabolic syndrome in women with polycystic ovary syndrome. Biochem Biophys Res Commun 2008;373:230-234.

37 Loos RJ, Bouchard C: FTO: the first gene contributing to common forms of human obesity. Obes Rev 2008;9:246-250.

38 Wahlen K, Sjolin E, Hoffstedt J: The common rs9939609 gene variant of the fat mass- and obesityassociated gene FTO is related to fat cell lipolysis. J Lipid Res 2008;49:607-611.

39 Barber TM, Bennett AJ, Groves CJ, Sovio U, Ruokonen A, Martikainen H, Pouta A, Hartikainen AL, Elliott P, Lindgren CM, Freathy RM, Koch K, Ouwehand WH, Karpe F, Conway GS, Wass JA, Jarvelin MR, Franks S, McCarthy MI: Association of variants in the fat mass and obesity associated (FTO) gene with polycystic ovary syndrome. Diabetologia 2008;51:1153-1158.

40 Wickenheisser JK, Nelson-DeGrave VL, McAllister JM: Human ovarian theca cells in culture. Trends Endocrinol Metab 2006;17:65-71.

41 Baillargeon JP, Nestler JE: Commentary: polycystic ovary syndrome: a syndrome of ovarian hypersensitivity to insulin? J Clin Endocrinol Metab 2006; 91:22-24.

42 Gambineri A, Pelusi C, Vicennati V, Pagotto U, Pasquali R: Obesity and the polycystic ovary syndrome. Int J Obes Relat Metab Disord 2002;26:883-896.

43 Hoeger KM: Obesity and lifestyle management in polycystic ovary syndrome. Clin Obstet Gynecol 2007;50:277-294.

44 Grodstein F, Goldman MB, Cramer DW: Body mass index and ovulatory infertility. Epidemiology 1994:5:247-250.

45 Pagotto U, Gambineri A, Vicennati V, Heiman ML, Tschop M, Pasquali R: Plasma ghrelin, obesity, and the polycystic ovary syndrome: correlation with insulin resistance and androgen levels. J Clin Endocrinol Metab 2002;87:5625-5629.

46 Schofl C, Horn R, Schill T, Schlosser HW, Müller MJ, Brabant G: Circulating ghrelin levels in patients with polycystic ovary syndrome. J Clin Endocrinol Metab 2002;87:4607-4610.

47 Moran L J, Noakes M, Clifton PM, Wittert GA, Tomlinson L, Galletly C, Luscombe ND, Norman RJ: Ghrelin and measures of satiety are altered in polycystic ovary syndrome but not differentially affected by diet composition. J Clin Endocrinol Metab 2004;89:3337-3344.

48 Glintborg D, Andersen M, Hagen C, Frystyk J, Hulstrom V, Flyvbjerg A, Hermann AP: Evaluation of metabolic risk markers in polycystic ovary syndrome (PCOS). Adiponectin, ghrelin, leptin and body composition in hirsute PCOS patients and controls. Eur J Endocrinol 2006;155:337-345.

49 Micic D, Sumarac-Dumanovic M, Kendereski A, Cvijovic G, Zoric S, Pejkovic D, Micic J, Milic N, Dieguez C, Casanueva FF: Total ghrelin levels during acute insulin infusion in patients with polycystic ovary syndrome. J Endocrinol Invest 2007;30:820827

50 Orio F Jr, Lucidi P, Palomba S, Tauchmanova L, Cascella T, Russo T, Zullo F, Colao A, Lombardi G, De Feo P: Circulating ghrelin concentrations in the polycystic ovary syndrome. J Clin Endocrinol Metab 2003;88:942-945.

51 Kos-Kudla B, Malecka-Mikosz O, Foltyn W, Ostrowska Z, Kudla M, Mazur B: Plasma ghrelin concentrations in patients with polycystic ovary syndrome before and after 6months therapy: correlation with androgen levels. Neuro Endocrinol Lett 2006;27:763-767.
2 Barber TM, Casanueva FF, Karpe F, Lage M, Franks S, McCarthy MI, Wass JA: Ghrelin levels are suppressed and show a blunted response to oral glucose in women with polycystic ovary syndrome. Eur J Endocrinol 2008;158:511-516.

53 Moran LJ, Noakes M, Clifton PM, Wittert GA, Le Roux CW, Ghatei MA, Bloom SR, Norman RJ Postprandial ghrelin, cholecystokinin, peptide YY and appetite before and after weight loss in overweight women with and without polycystic ovary syndrome. Am J Clin Nutr 2007;86:1603-1610.

54 Baranowska B, Radzikowska M, Wasilewska-Dziubinska E, Kaplinski A, Roguski K, Plonowski A: Neuropeptide Y, leptin, galanin and insulin in women with polycystic ovary syndrome. Gynecol Endocrinol 1999;13:344-351.

55 Gennarelli G, Holte J, Stridsberg M, Niklasson F, Berne C, Backstrom T: The counterregulatory response to hypoglycaemia in women with the polycystic ovary syndrome. Clin Endocrinol (Oxf) 1997;46:167-174.

56 Dokras A: Cardiovascular disease risk factors in polycystic ovary syndrome. Semin Reprod Med 2008; 26:39-44.

57 Cho L W, Atkin SL: Cardiovascular risk in women with polycystic ovary syndrome. Minerva Endocrinol 2007;32:263-273.

58 Cibula D, Cifkova R, Fanta M, Poledne R, Zivny J, Skibova J: Increased risk of non-insulin dependent diabetes mellitus, arterial hypertension and coronary artery disease in perimenopausal women with a history of the polycystic ovary syndrome. Hum Reprod 2000;15:785-789.

59 Ehrmann DA, Barnes RB, Rosenfield RL, Cavaghan MK, Imperial J: Prevalence of impaired glucose tolerance and diabetes in women with polycystic ovary syndrome. Diabetes Care 1999;22:141-146.

60 Legro RS, Kunselman AR, Dodson WC, Dunaif A: Prevalence and predictors of risk for type 2 diabetes mellitus and impaired glucose tolerance in polycystic ovary syndrome: a prospective, controlled study in 254 affected women . J Clin Endocrinol Metab 1999;84:165-169.

61 Vrbikova J, Cifkova R, Jirkovska A, Lanska V, Platilova H, Zamrazil V, Starka L: Cardiovascular risk factors in young Czech females with polycystic ovary syndrome. Hum Reprod 2003;18:980-984.

62 Weerakiet S, Srisombut C, Bunnag P, Sangtong S, Chuangsoongnoen N, Rojanasakul A: Prevalence of type 2 diabetes mellitus and impaired glucose tolerance in Asian women with polycystic ovary syndrome. Int J Gynaecol Obstet 2001;75:177-184.

63 Norman RJ, Masters L, Milner CR, Wang JX, Davies MJ: Relative risk of conversion from normoglycaemia to impaired glucose tolerance or non-insulin dependent diabetes mellitus in polycystic ovarian syndrome. Hum Reprod 2001;16:1995-1998.

64 Gambineri A, Pelusi C, Manicardi E, Vicennati V, Cacciari M, Morselli-Labate A M, Pagotto U, Pasquali R: Glucose intolerance in a large cohort of mediterranean women with polycystic ovary syndrome: phenotype and associated factors. Diabetes 2004;53:2353-2358.

65 Vrbikova J, Dvorakova K, Grimmichova T, Hill M, Stanicka S, Cibula D, Bendlova B, Starka L, Vondra K: Prevalence of insulin resistance and prediction of glucose intolerance and type 2 diabetes mellitus in women with polycystic ovary syndrome. Clin Chem Lab Med 2007;45:639-644.

66 Salley KE, Wickham EP, Cheang KI, Essah PA, Karjane NW, Nestler JE: Glucose intolerance in polycystic ovary syndrome - a position statement of the Androgen Excess Society. J Clin Endocrinol Metab 2007;92:4546-4556. 
67 Vrbikova J, Vondra K, Cibula D, Dvorakova K, Stanicka S, Sramkova D, Sindelka G, Hill M, Bendlova B, Skrha J: Metabolic syndrome in young Czech women with polycystic ovary syndrome. Hum Reprod 2005;20:3328-3332.

68 Soares EM, Azevedo GD, Gadelha RG, Lemos TM, Maranhao TM: Prevalence of the metabolic syndrome and its components in Brazilian women with polycystic ovary syndrome. Fertil Steril 2008;89: 649-655.

69 Glueck CJ, Papanna R, Wang P, Goldenberg N, Sieve-Smith L: Incidence and treatment of metabolic syndrome in newly referred women with confirmed polycystic ovarian syndrome. Metabolism 2003;52:908-915.

70 Apridonidze T, Essah PA, Iuorno MJ, Nestler J E: Prevalence and characteristics of the metabolic syndrome in women with polycystic ovary syndrome. $\mathrm{J}$ Clin Endocrinol Metab 2005;90:1929-1935.

71 Wild RA: Polycystic ovary syndrome: a risk for coronary artery disease? Am J Obstet Gynecol 2002; 186:35-43.

72 Luque-Ramirez M, Alvarez-Blasco F, MendietaAzcona C, Botella-Carretero J I, Escobar-Morreale HF: Obesity is the major determinant of the abnormalities in blood pressure found in young women with the polycystic ovary syndrome. J Clin Endocrinol Metab 2007;92:2141-2148.

73 Rizzo M, Berneis K, Carmina E, Rini GB: How should we manage atherogenic dyslipidemia in women with polycystic ovary syndrome? Am J Obstet Gynecol 2008;198:28.e21-25.

74 Diamanti-Kandarakis E, Papavassiliou AG, Kandarakis S A, Chrousos GP: Pathophysiology and types of dyslipidemia in PCOS. Trends Endocrinol Metab 2007;18:280-285.

75 Elting MW, Korsen TJ, Schoemaker J: Obesity, rather than menstrual cycle pattern or follicle cohort size, determines hyperinsulinaemia, dyslipidaemia and hypertension in ageing women with polycystic ovary syndrome. Clin Endocrinol (Oxf) 2001;55:767-776.

76 Mohlig M, Spranger J, Osterhoff M, Ristow M, Pfeiffer AF, Schill T, Schlosser H W, Brabant G, Schofl C: The polycystic ovary syndrome per se is not associated with increased chronic inflammation. Eur J Endocrinol 2004;150:525-532.

77 Escobar-Morreale HF, Villuendas G, Botella-Carretero JI, Sancho J, San Millan JL: Obesity, and not insulin resistance, is the major determinant of serum inflammatory cardiovascular risk markers in premenopausal women. Diabetologia 2003;46:625-633.

-78 Ketel IJ, Stehouwer CD, Serne EH, Korsen TJ, Hompes PG, Smulders YM, de Jongh RT, Homburg R, Lambalk CB: Obese but not normal-weight women with polycystic ovary syndrome are characterized by metabolic and microvascular insulin resistance. J Clin Endocrinol Metab 2008;93:3365-3372.

79 Kerchner A, Lester W, Stuart SP, Dokras A: Risk of depression and other mental health disorders in women with polycystic ovary syndrome: a longitudinal study. Fertil Steril 2009;91:207-212.

80 Barnard L, Ferriday D, Guenther N, Strauss B, Balen A H, Dye L: Quality of life and psychological well being in polycystic ovary syndrome. Hum Reprod 2007;22:2279-2286.

81 Hollinrake E, Abreu A, Maifeld M, Van Voorhis B J, Dokras A: Increased risk of depressive disorders in women with polycystic ovary syndrome. Fertil Steril 2007;87:1369-1376.

82 Mansson M, Holte J, Landin-Wilhelmsen K, Dahlgren $\mathrm{E}$, Johansson A, Landen M: Women with polycystic ovary syndrome are often depressed or anxious-A case control study. Psychoneuroendocrinology 2008;33:1132-1138.
83 Himelein MJ, Thatcher SS: Polycystic ovary syndrome and mental health: a review. Obstet Gynecol Surv 2006;61:723-732.

84 Jones GL, Hall JM, Balen AH, Ledger WL: Healthrelated quality of life measurement in women with polycystic ovary syndrome: a systematic review. Hum Reprod Update 2008;14:15-25.

85 Weber B, Lewicka S, Deuschle M, Colla M, Heuser I: Testosterone, androstenedione and dihydrotestosterone concentrations are elevated in female patients with major depression. Psychoneuroendocrinology 2000;25:765-771.

86 Weiner CL, Primeau M, Ehrmann DA: Androgens and mood dysfunction in women: comparison of women with polycystic ovarian syndrome to healthy controls. Psychosom Med 2004;66:356-362.

87 Rasgon NL, Rao RC, Hwang S, Altshuler LL, Elman S, Zuckerbrow-Miller J, Korenman SG: Depression in women with polycystic ovary syndrome: clinical and biochemical correlates. J Affect Disord 2003;74:299-304.

88 Timonen M, Salmenkaita I, Jokelainen J, Laakso M, Harkonen P, Koskela P, Meyer-Rochow VB, Peitso A, Keinanen-Kiukaanniemi S: Insulin resistance and depressive symptoms in young adult males: findings from Finnish military conscripts. Psychosom Med 2007;69:723-728.

89 Koulouri O, Conway GS: A systematic review of commonly used medical treatments for hirsutism in women. Clin Endocrinol (Oxf) 2008;68:800-805.

90 Cibula D, Hill M, Fanta M, Sindelka G, Zivny J: Does obesity diminish the positive effect of oral contraceptive treatment on hyperandrogenism in women with polycystic ovarian syndrome? Hum Reprod 2001;16:940-944.

91 Nader S, Diamanti-Kandarakis E: Polycystic ovary syndrome, oral contraceptives and metabolic issues: new perspectives and a unifying hypothesis. Hum Reprod 2007;22:317-322.

92 Cibula D, Sindelka G, Hill M, Fanta M, Skrha J, Zivny J: Insulin sensitivity in non-obese women with polycystic ovary syndrome during treatment with oral contraceptives containing low-androgenic progestin. Hum Reprod 2002;17:76-82.

93 Luque-Ramirez M, Alvarez-Blasco F, BotellaCarretero JI, Martinez-Bermejo E, Lasuncion MA, Escobar-Morreale HF: Comparison of ethinylestradiol plus cyproterone acetate versus metformin effects on classic metabolic cardiovascular risk factors in women with the polycystic ovary syndrome. J Clin Endocrinol Metab 2007;92:2453-2461.

94 Meyer C, McGrath BP, Teede HJ: Effects of medical therapy on insulin resistance and the cardiovascular system in polycystic ovary syndrome. Diabetes Care 2007;30:471-478.

95 Vrbikova J, Cibula D: Combined oral contraceptives in the treatment of polycystic ovary syndrome. Hum Reprod Update 2005;11:277-291.

96 Baillargeon JP, McClish DK, Essah PA, Nestler JE: Association between the current use of lowdose oral contraceptives and cardiovascular arterial disease: a meta-analysis. J Clin Endocrinol Metab 2005;90:3863-3870

97 Lord JM, Flight IH, Norman RJ: Insulin-sensitising drugs (metformin, troglitazone, rosiglitazone, pioglitazone, D-chiro-inositol) for polycystic ovary syndrome. Cochrane Database Syst Rev 2003; CD003053.

98 Cosma M, Swiglo BA, Flynn DN, Kurtz DM, Labella ML, Mullan RJ, Elamin MB, Erwin PJ, Montori VM: Clinical review: Insulin sensitizers for the treatment of hirsutism: a systematic review and metaanalyses of randomized controlled trials. J Clin Endocrinol Metab 2008;93:1135-1142.
99 Swiglo BA, Cosma M, Flynn DN, Kurtz DM, Labella ML, Mullan RJ, Erwin PJ, Montori VM: Clinical review: Antiandrogens for the treatment of hirsutism: a systematic review and metaanalyses of randomized controlled trials. J Clin Endocrinol Metab 2008;93:1153-1160.

100 UK Prospective Diabetes Study (UKPDS) Group: Effect of intensive blood-glucose control with metformin on complications in overweight patients with type 2 diabetes (UKPDS 34). Lancet 1998;352:854-865.

101 Wulffele MG, Kooy A, de Zeeuw D, Stehouwer CD, Gansevoort RT: The effect of metformin on blood pressure, plasma cholesterol and triglycerides in type 2 diabetes mellitus: a systematic review. J Intern Med 2004;256:1-14.

102 Harborne L, Fleming R, Lyall H, Sattar N, Norman J: Metformin or antiandrogen in the treatment of hirsutism in polycystic ovary syndrome. $\mathrm{J}$ Clin Endocrinol Metab 2003;88:4116-4123.

103 Morin-Papunen L, Vauhkonen I, Koivunen R, Ruokonen A, Martikainen H, Tapanainen JS: Metformin versus ethinyl estradiol-cyproterone acetate in the treatment of nonobese women with polycystic ovary syndrome: a randomized study. $\mathrm{J}$ Clin Endocrinol Metab 2003;88:148-156.

104 Morin-Papunen LC, Vauhkonen I, Koivunen RM, Ruokonen A, Martikainen HK, Tapanainen JS: Endocrine and metabolic effects of metformin versus ethinyl estradiol- cyproterone acetate in obese women with polycystic ovary syndrome: a randomized study. J Clin Endocrinol Metab 2000;85:3161-3168.

105 Costello M, Shrestha B, Eden J, Sjoblom P, Johnson N: Insulin-sensitising drugs versus the combined oral contraceptive pill for hirsutism, acne and risk of diabetes, cardiovascular disease, and endometrial cancer in polycystic ovary syndrome. Cochrane Database Syst Rev 2007;CD005552.

106 Azziz R, Ehrmann D, Legro RS, Whitcomb RW, Hanley R, Fereshetian AG, O'Keefe M, Ghazzi $\mathrm{MN}$ : Troglitazone improves ovulation and hirsutism in the polycystic ovary syndrome: a multicenter, double blind, placebo-controlled trial. J Clin Endocrinol Metab 2001;86:1626-1632.

107 Brettenthaler N, De Geyter C, Huber PR, Keller $\mathrm{U}$ : Effect of the insulin sensitizer pioglitazone on insulin resistance, hyperandrogenism, and ovulatory dysfunction in women with polycystic ovary syndrome. J Clin Endocrinol Metab 2004;89:38353840 .

108 Goldberg RB, Kendall DM, Deeg MA, Buse JB, Zagar AJ, Pinaire JA, Tan MH, Khan MA, Perez AT, Jacober SJ: A comparison of lipid and glycemic effects of pioglitazone and rosiglitazone in patients with type 2 diabetes and dyslipidemia. Diabetes Care 2005;28:1547-1554.

109 Lemay A, Dodin S, Turcot L, Dechene F, Forest JC: Rosiglitazone and ethinyl estradiol/cyproterone acetate as single and combined treatment of overweight women with polycystic ovary syndrome and insulin resistance. Hum Reprod 2006; 21:121-128.

110 Ortega-Gonzalez C, Luna S, Hernandez L, Crespo G, Aguayo P, Arteaga-Troncoso G, Parra A: Responses of serum androgen and insulin resistance to metformin and pioglitazone in obese, insulinresistant women with polycystic ovary syndrome. J Clin Endocrinol Metab 2005;90:1360-1365.

111 Nissen SE, Wolski K: Effect of rosiglitazone on the risk of myocardial infarction and death from cardiovascular causes. N Engl J Med 2007;356: 2457-2471. 
112 Huber-Buchholz MM, Carey DG, Norman RJ: Restoration of reproductive potential by lifestyle modification in obese polycystic ovary syndrome: role of insulin sensitivity and luteinizing hormone. J Clin Endocrinol Metab 1999;84:1470-1474.

113 Kiddy DS, Hamilton-Fairley D, Bush A, Short F, Anyaoku V, Reed MJ, Franks S: Improvement in endocrine and ovarian function during dietary treatment of obese women with polycystic ovary syndrome. Clin Endocrinol (Oxf) 1992;36:105111.

114 Pasquali R, Casimirri F, Vicennati V: Weight control and its beneficial effect on fertility in women with obesity and polycystic ovary syndrome. Hum Reprod 1997;12(suppl 1):82-87.

-115 Gambineri A, Pelusi C, Genghini S, MorselliLabate AM, Cacciari M, Pagotto U, Pasquali R: Effect of flutamide and metformin administered alone or in combination in dieting obese women with polycystic ovary syndrome. Clin Endocrinol (Oxf) 2004;60:241-249.

- 116 Holte J, Bergh T, Berne C, Wide L, Lithell H: Restored insulin sensitivity but persistently increased early insulin secretion after weight loss in obese women with polycystic ovary syndrome. J Clin Endocrinol Metab 1995;80:2586-2593.

117 Moran LJ, Noakes M, Clifton PM, Tomlinson L, Galletly C, Norman RJ: Dietary composition in restoring reproductive and metabolic physiology in overweight women with polycystic ovary syndrome. J Clin Endocrinol Metab 2003;88:812-819.

-118 Pasquali R, Gambineri A, Biscotti D, Vicennati V, Gagliardi L, Colitta D, Fiorini S, Cognigni GE, Filicori M, Morselli-Labate AM: Effect of long-term treatment with metformin added to hypocaloric diet on body composition, fat distribution, and androgen and insulin levels in abdominally obese women with and without the polycystic ovary syndrome. J Clin Endocrinol Metab 2000;85:2767-2774.

119 Wahrenberg H, Ek I, Reynisdottir S, Carlstrom K, Bergqvist A, Arner P: Divergent effects of weight reduction and oral anticonception treatment on adrenergic lipolysis regulation in obese women with the polycystic ovary syndrome. J Clin Endocrinol Metab 1999;84:2182-2187.

120 Klein S, Sheard NF, Pi-Sunyer X, Daly A, Wylie-Rosett J, Kulkarni K, Clark NG: Weight management through lifestyle modification for the prevention and management of type 2 diabetes: rationale and strategies. A statement of the American Diabetes Association, the North American Association for the Study of Obesity, and the American Society for Clinical Nutrition. Am J Clin Nutr 2004;80:257-263.

-121 Thessaloniki ESHRE/ASRM-Sponsored PCOS Consensus Workshop Group: Consensus on infertility treatment related to polycystic ovary syndrome. Fertil Steril 2008;89:505-522.

122 Palomba S, Pasquali R, Orio F Jr, Nestler JE: Clomiphene citrate, metformin or both as firststep approach in treating anovulatory infertility in patients with polycystic ovary syndrome (PCOS): a systematic review of head-to-head randomized controlled studies and meta-analysis. Clin Endocrinol (Oxf) 2008;DOI: 10.1111/j.13652265.2008.03369.x

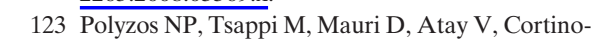
vis I, Casazza G: Aromatase inhibitors for infertility in polycystic ovary syndrome. The beginning or the end of a new era? Fertil Steril 2008;89:278280.
124 Katcher HI, Kunselman AR, Dmitrovic R, Demers LM, Gnatuk CL, Kris-Etherton PM, Legro RS: Comparison of hormonal and metabolic markers after a high-fat, Western meal versus a low-fat, high-fiber meal in women with polycystic ovary syndrome. Fertil Steril 2008;DOI: $10.1016 /$ j.fertnstert.2008.01.035.

125 Kasim-Karakas SE, Cunningham WM, Tsodikov A: Relation of nutrients and hormones in polycystic ovary syndrome. Am J Clin Nutr 2007;85:688-694.

126 Stamets K, Taylor DS, Kunselman A, Demers LM, Pelkman CL, Legro RS: A randomized trial of the effects of two types of short-term hypocaloric diets on weight loss in women with polycystic ovary syndrome. Fertil Steril 2004;81:630-637.

127 Douglas CC, Gower BA, Darnell BE, Ovalle F, Oster RA, Azziz R: Role of diet in the treatment of polycystic ovary syndrome. Fertil Steril 2006;85:679-688.

128 Kasim-Karakas SE, Almario RU, Gregory L, Wong R, Todd H, Lasley BL: Metabolic and endocrine effects of a polyunsaturated fatty acidrich diet in polycystic ovary syndrome. J Clin Endocrinol Metab 2004;89:615-620.

129 Galletly C, Moran L, Noakes M, Clifton P, Tomlinson L, Norman R: Psychological benefits of a high-protein, low-carbohydrate diet in obese women with polycystic ovary syndrome - a pilot study. Appetite 2007;49:590-593.

130 Moran LJ, Noakes M, Clifton PM, Wittert GA, Williams G, Norman RJ: Short-term meal replacements followed by dietary macronutrient restriction enhance weight loss in polycystic ovary syndrome. Am J Clin Nutr 2006;84:77-87.

131 Levitan EB, Cook NR, Stampfer MJ, Ridker PM, Rexrode KM, Buring JE, Manson JE, Liu S: Dietary glycemic index, dietary glycemic load, blood lipids, and C-reactive protein. Metabolism 2008;57:437-443.

132 Augustin LS, Gallus S, Bosetti C, Levi F, Negri E, Franceschi S, Dal Maso L, Jenkins DJ, Kendall CW, La Vecchia C: Glycemic index and glycemic load in endometrial cancer. Int $\mathrm{J}$ Cancer 2003;105:404-407.

133 Velazquez EM, Mendoza S, Hamer T, Sosa F, Glueck CJ: Metformin therapy in polycystic ovary syndrome reduces hyperinsulinemia, insulin resistance, hyperandrogenemia, and systolic blood pressure, while facilitating normal menses and pregnancy. Metabolism 1994;43:647-654.

134 Nieuwenhuis-Ruifrok AE, Kuchenbecker WK, Hoek A, Middleton P, Norman RJ: Insulin sensitizing drugs for weight loss in women of reproductive age who are overweight or obese: systematic review and meta-analysis. Hum Reprod Update 2008;15:57-68,

135 Franz MJ, VanWormer JJ, Crain AL, Boucher JL, Histon T, Caplan W, Bowman JD, Pronk NP: Weight-loss outcomes: a systematic review and meta-analysis of weight-loss clinical trials with a minimum 1-year follow-up. J Am Diet Assoc 2007;107:1755-1767.

136 Cho L, Kilpatrick E, Keevil B, Coady A, Atkin S: Effect of metformin, orlistat and pioglitazone treatment on mean insulin resistance and its biological variability in polycystic ovary syndrome. Clin Endocrinol (Oxf) 2008;DOI: 10.1111/j.13652265.2008.03309.x.
137 Diamanti-Kandarakis E, Katsikis I, Piperi C, Alexandraki K, Panidis D: Effect of long-term orlistat treatment on serum levels of advanced glycation end-products in women with polycystic ovary syndrome. Clin Endocrinol (Oxf) 2007;66:103109.

138 Jayagopal V, Kilpatrick ES, Holding S, Jennings PE, Atkin SL: Orlistat is as beneficial as metformin in the treatment of polycystic ovarian syndrome. J Clin Endocrinol Metab 2005;90:729_ 733.

139 Panidis D, Farmakiotis D, Rousso D, Kourtis A Katsikis I, Krassas G: Obesity, weight loss, and the polycystic ovary syndrome: effect of treatment with diet and orlistat for 24 weeks on insulin resistance and androgen levels. Fertil Steril 2008; 89:899-906.

140 Florakis D, Diamanti-Kandarakis E, Katsikis I, Nassis GP, Karkanaki A, Georgopoulos N, Panidis D: Effect of hypocaloric diet plus sibutramine treatment on hormonal and metabolic features in overweight and obese women with polycystic ovary syndrome: a randomized, 24week study. Int J Obes (Lond) 2008;32:692-699.

141 Lindholm A, Bixo M, Bjorn I, Wolner-Hanssen P, Eliasson M, Larsson A, Johnson O, Poromaa IS: Effect of sibutramine on weight reduction in women with polycystic ovary syndrome: a randomized, double-blind, placebo-controlled trial. Fertil Steril 2008;89:1221-1228.

142 Sabuncu T, Harma M, Harma M, Nazligul Y, Kilic F: Sibutramine has a positive effect on clinical and metabolic parameters in obese patients with polycystic ovary syndrome. Fertil Steril 2003;80: 1199-1204.

143 Sathyapalan T, Cho L, Kilpatrick ES, Coady AM, Atkin SL: A comparison between rimonabant and metformin in reducing biochemical hyperandrogenaemia and insulin resistance in patients with polycystic ovary syndrome: a randomised open labelled parallel study. Clin Endocrinol (Oxf) 2008; 69:931-35.

144 Rimonabant: suicide and depression. Depression and suicidal tendencies are about twice as frequent with rimonabant as with placebo. Prescrire Int 2007;16:250.

145 European Medicines Agency: EPARs for authorised medicinal products for human use. www. emea.europa.eu/humandocs/Humans/EPAR/ acomplia/acomplia.htm

146 Appolinario JC, Bueno JR, Coutinho W: Psychotropic drugs in the treatment of obesity: what promise? CNS Drugs 2004;18:629-651.

147 Fried M, Hainer V, Basdevant A, Buchwald H, Deitel M, Finer N, Greve JW, Horber F, Mathus-Vliegen E, Scopinaro N, Steffen R, Tsigos C, Weiner R, Widhalm K: Interdisciplinary European guidelines for surgery for severe (morbid) obesity. Obesity Facts 2008;1:52-59.

148 Martin LF, Finigan KM, Nolan TE: Pregnancy after adjustable gastric banding. Obstet Gynecol 2000;95:927-930.

-149 Eid GM, Cottam DR, Velcu LM, Mattar SG, Korytkowski MT, Gosman G, Hindi P, Schauer PR: Effective treatment of polycystic ovarian syndrome with Roux-en-Y gastric bypass. Surg Obes Relat Dis 2005;1:77-80. 